\title{
OPEN Publisher Correction: In-hospital recurrence in a Chinese large cohort with acute ischemic stroke
}

\section{Fan Yu, Xiaolu Liu, Qiong Yang, Yu Fu \& Dongsheng Fan}

Correction to: Scientific Reports https://doi.org/10.1038/s41598-019-51277-8, published online 18 October 2019

The original version of this Article omitted an affiliation for Fan Yu. The correct affiliations for Fan Yu are listed below:

Department of Neurology, Peking University Third Hospital, Beijing, China

Department of Neurology, Yulin No.2 Hospital, Yulin, Shaanxi Province, China

This has now been corrected in the HTML and PDF versions of this Article.

(c) (i) Open Access This article is licensed under a Creative Commons Attribution 4.0 International License, which permits use, sharing, adaptation, distribution and reproduction in any medium or format, as long as you give appropriate credit to the original author(s) and the source, provide a link to the Creative Commons license, and indicate if changes were made. The images or other third party material in this article are included in the article's Creative Commons license, unless indicated otherwise in a credit line to the material. If material is not included in the article's Creative Commons license and your intended use is not permitted by statutory regulation or exceeds the permitted use, you will need to obtain permission directly from the copyright holder. To view a copy of this license, visit http://creativecommons.org/licenses/by/4.0/.

(C) The Author(s) 2019 